Egyptian Journal of Aquatic Biology \& Fisheries

Zoology Department, Faculty of Science,

Ain Shams University, Cairo, Egypt.

ISSN $1110-6131$

Vol. 22(5): 419- 429 (2018)

www.ejabf.journals.ekb.eg

\title{
Nutritional value and health quotient of algae collected from Egyptian coast,
} Alexandria

\author{
Dalia M. S. A. Salem ${ }^{1 *}$, Amany El Sikaily ${ }^{2}$ and Amal E.A. Abou-taleb ${ }^{1}$ \\ 1-Marine Chemistry Laboratory, Marine Environment Division, National Institute of \\ Oceanography and Fisheries, Alexandria, Egypt. \\ 2- Marine Pollution Laboratory, Marine Environment Division, National Institute of \\ Oceanography and Fisheries, Alexandria, Egypt. \\ * Corresponding author.+20 1112625503; prof_dalia@yahoo.com
}

\begin{abstract}
ARTICLE INFO
Article History:

Received: Sept. 22, 2018

Accepted: Nov. 29, 2018

Online: Dec. 30, 2018
\end{abstract}

Keywords:

Seawater

Algae

Essential minerals

Essential Trace elements

Proximate content

Nutrition
ABSTRACT

Algal species have considerable benefits to human, because of their great nutritional value. Thus, we investigated the nutrient content (essential minerals and trace elements) and the biochemical composition (proximate content) of macroalgae (green, brown and red algae). The results indicated the existance of high concentrations of the essential minerals as $\mathrm{Na}, \mathrm{K}, \mathrm{Ca}$ and $\mathrm{Mg}$. Brown algae gave high $\mathrm{Na}$ and $\mathrm{K}$ values followed by red and green algae. While, $\mathrm{Ca}$ and $\mathrm{Mg}$ were distributed in high concentrations in red algae followed by brown and green algae. On the other hand, the essential trace elements $(\mathrm{Fe}, \mathrm{Cu}, \mathrm{Zn}$ and $\mathrm{Mn}$ ) followed as $\mathrm{Fe}>\mathrm{Mn}>\mathrm{Zn}>\mathrm{Cu}$. Proximate content of algae (carbohydrates and proteins) in the three types of algae recorded as follow, for carbohydrates red algae > green algae > brown algae. Meanwhile, proteins concentration followed as red algae > brown algae > green algae. Finally, ion quotients are between 0.208 and 2.019 for green algae species, between 0.722 and 2.087 for brown algae and between 0.458 and 2.433 for red algae. The nutrient content of studied stations water was investigated as well. From the concentration values of essential minerals in studied stations water, it was found that, Agamy station has the smallest values of $\mathrm{Na}(10.560 \mathrm{~g} / \mathrm{l}), \mathrm{K}(0.463 \mathrm{~g} / \mathrm{l}), \mathrm{Ca}(0.473 \mathrm{~g} / \mathrm{l})$ and $\mathrm{Mg}(1.573 \mathrm{~g} / \mathrm{l})$. The essential trace elements in stations water followed as $\mathrm{Fe}>\mathrm{Cu}>\mathrm{Zn}>\mathrm{Mn}$. The highest values of $\mathrm{Fe}(565.500 \mathrm{Mg} / \mathrm{l}), \mathrm{Zn}(20.756 \mathrm{Mg} / \mathrm{l})$ and $\mathrm{Mn}$ (4.803 $\mathrm{Mg} / \mathrm{l})$ were recorded at $\mathrm{Abu}$ Quir station while, $\mathrm{Cu}$ measured the highest value (28.260 Mg/l) at Agamy station.

\section{INTRODUCTION}

Algae using are progressively increased because of their functional benefits in addition to their traditional importance for health and nutrition. Beside their role as basic nutrition, algae are consumed as nutraceuticals, that may avail for health (e.g., disease prevention and anti-inflammatories) (Bagchi, 2006; Hafting et al., 2012). The algae are utilized as food for humans and animals, production of colloids (alginates, agar, furcelaran and carrageenan), soil compost, pharmaceuticals and cosmotics beside extraction of salts (iodine and soda). In the south east Asia countries algae represent one of economic resources where they are largely harvested and used in the human nutrition (Rupérez, 2002). Furthermore, algae are very useful as bioindicator 
for studying the contamination of environment (Cost, 1987; Cost, 1989; Caliceti et al., 2002). The algae composition varies according to species, year season, water temperature and geographic area (Jensen, 1993).

The algae minerals are helpful in developing the metabolic reactions. The inorganic elements or minerals are present in all tissues of body and necessary to preserve some physico-chemical processes which are necessary for life. Every shape of living matter needs these inorganic elements for its ordinary vital activities (Hays and Swenson, 1985; Ozcan, 2003). Minerals are categorized into three categories, macro (major), micro (trace) and ultra trace elements. The macro-elements comprise phosphorus, chloride, calcium and sodium, while the micro-minerals comprise copper, zinc, iron, magnesium, potassium, cobalt, iodine, manganese, molybdenum, chromium, fluoride, sulfur and selenium (Eruvbetine, 2003). Carbohydrates of algae include glucose, starch and polysaccharides which are more digestible. Therefore, it is possible to use algae in feed and dried food (Becker, 2004).

The target of this work is to assess the nutrition value of some algal species collected along Alexandria coast, Egypt.

\section{MATERIALS AND METHODS}

\section{Study area}

The sampling stations of water and marine algae at the Egyptian Mediterranean Sea coast of Alexandria region (Abu Quir, Sheraton, Stanly, El-Shatby, Eastern Harbour and Agamy) were shown in Figure1.

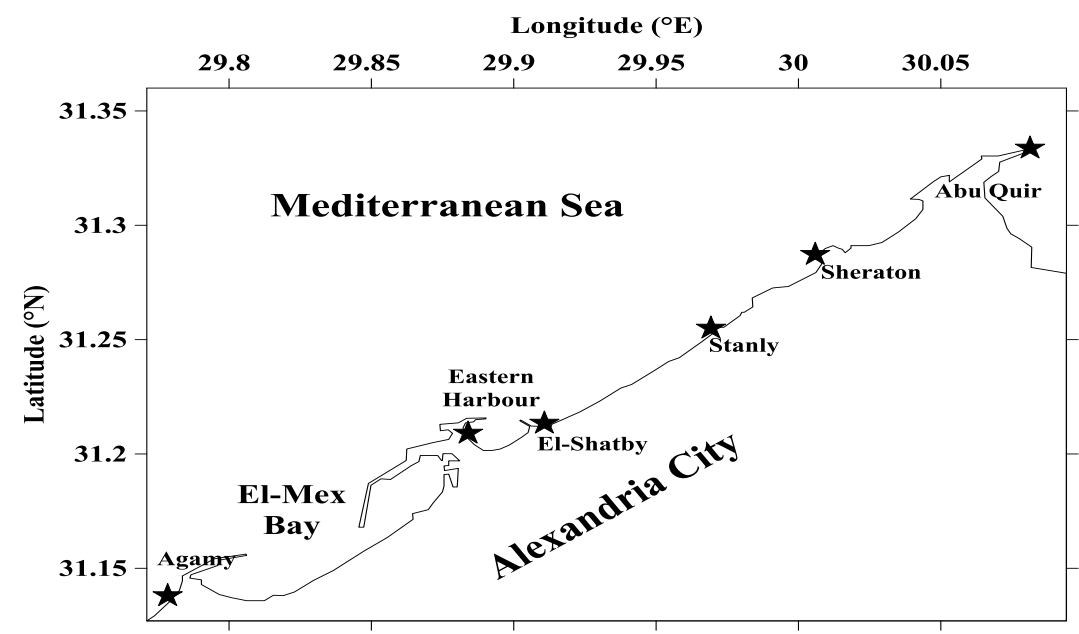

Fig. 1: Studied stations along Egyptian Mediterranean Sea coast, Alexandria.

\section{Algae collection}

Different algal species of different classes including, Amphiroa rigida, Corollina officinalis, Pterocladiacapillacea and Jania rubens; Division Rhodophyceae, Ulva linzea and Ulva fasciata; Division Chlorophyceae and Colpomenia sinuosa and Sargassum vulgare; Division Phaeophyceae were handpicked collected along Alexandria coast stations in the subtidal zone. The collected samples were nearly at the same stage of growth. Washing of picked algae in seawater at the collcting place was done. The samples were refrigerated and carried to the laboratory. On the laboratory, they were cleaned carefully under tap water. Identification of samples was carried out by species (Aleem, 1993; Riedel, 1970). Finally, small weight of each collected species was frozen and kept at $4{ }^{\circ} \mathrm{C}$ until 
proximate content (carbohydrates and proteins) analysis. After that all species were air dried, kept in oven overnight at $30{ }^{\circ} \mathrm{C}$ and grinded to pass a 20 mesh-screen. The grinded materials were stored in plastic bags.

\section{Chemical analyses \\ Water analysis}

Surface seawater were taken from coastal area of Abu-Quir to Agamy using Niskin bottles (Figure 1). At the same time of sampling, the temperature of seawater was recorded by a pocket thermometer. Salinity of seawater was measured using induction salinometer (Beckman model RS-10). The $\mathrm{pH}$ of seawater was recorded by a digital Jenway $3505 \mathrm{pH}$ meter. Total alkalinity (TA) of collected samples was directly analyzed using volumetric titration against standard $0.01 \mathrm{~N}$ hydrochloric acid in presence of methyl orange (APHA,1999). Oxidizable organic matter (OOM) was analyzed using the method reported by FAO (1976). Dissolved oxygen (DO) was dtermined using Winkler's method with standard iodimetric titration (Strickland and Parsons, 1972). Ammonium ion concentrations were determined spectrophotometrically using the indophenol blue technique (IOC, 1983). Chlorophyll-a (Chl-a) was measured spectrophotometrically using the method described by Strickland and Parsons (1972).

Essential minerals ( $\mathrm{Na}, \mathrm{K}, \mathrm{Ca}$ and $\mathrm{Mg}$ ) and essential trace elements ( $\mathrm{Fe}, \mathrm{Cu}, \mathrm{Zn}$ and Mn) analysis

For the studied essential minerals and essential trace elements, dried algae $(0.1$ g) was subjected to digestion in a solution containing the following concentrated acids; $\mathrm{HNO}_{3}, \mathrm{HF}$ and $\mathrm{HClO}_{4}$ (3:2:1) for $3 \mathrm{~h}$. The volume of the digested samples were reduced by heating. After that deionized distilled water was added to dilute each sample to final volum of $25 \mathrm{ml}$ using a poly tetrafluoroethylene flask. Finally the prepared solutions were filtrated and kept in PVC bottles. The investigated elements in studied stations water were determined after pre-concentration from seawater by using chelex-100 cation-exchange resins according to Riley and Taylor (1968). After these procedures, the concentrations of the essential trace elements $(\mathrm{Fe}, \mathrm{Cu}, \mathrm{Zn}$ and $\mathrm{Mn})$ in algae and seawater samples were determined utilizing atomic absorption spectrophotometer (AAS)/flame mode (Shimadzu AA-6800) $(\mathrm{Fe}, \lambda=372.0 \mathrm{~nm} ; \mathrm{Cu}, \lambda$ $=324.8 \mathrm{~nm} ; \mathrm{Zn}, \lambda=213.9 \mathrm{~nm}$ and $\mathrm{Mn}, \lambda=403.1 \mathrm{~nm}$ ) (MAA, 1998). Measurements were carried out in triplicate.

The essential minerals, $\mathrm{Na}$ and $\mathrm{K}$ were measured directly in digested algae and pre-concentrated seawater samples using Flame Photometer JENWAY Model PFP7 with a limit detection of $<0.2 \mathrm{ppm}$ for both elements. Calcium was determined by the conventional titrimetric method using EDTA (Ethylene diamine tetra acetic acid disodium salt) according to APHA (1999), in which the digested algae and preconcentrated seawater samples containing both $\mathrm{Ca}$ and $\mathrm{Mg}$ were adjusted to $\mathrm{pH}$ (1213) with buffer solution and titrated with EDTA using Murexide as an indicator. Total hardness $(\mathrm{Ca}$ and $\mathrm{Mg}$ ) in digested and pre-concentrated samples was determined by titration versus EDTA in presence of eriochrome black-T indicator and buffer solution to give $\mathrm{pH}$ (10). Magnesium was calculated from the difference between total hardness and Ca concentration values (APHA, 1999).

\section{Proximate content (carbohydrates and proteins) of algae Total carbohydrates analysis}

At the begining, the studied algae were extracted with $2.5 \mathrm{~N} \mathrm{HCl}$. After that total carbohydrates content in the different species of algae was determined by phenol/sulfuric acid method (DuBois et al., 1956). UV/Visible single beam 
spectronic 21 D Milton Roy spectrophotometer was used. Glucose standard curve was utilized for calculating the results (Schüep and Schierle, 1995).

\section{Proteins analysis}

Proteins content was assayed using UV/Visible single beam spectronic $21 \mathrm{D}$ Milton Roy spectrophotometer. Pierce test kit (BCA 23225) was utilized according to the methods of Lowry et al. (1954) and Kreeger et al. (1997). Standardization was done with bovine serum albumin and measurements were taken at $562 \mathrm{~nm}$.

\section{RESULTS}

The tested algae contained high quantity of the essential minerals $(\mathrm{Na}, \mathrm{K}, \mathrm{Ca}$ and $\mathrm{Mg})$. Green algae gave the following ranges of $\mathrm{Na}(0.678-1.340 \mathrm{mg} / \mathrm{g}), \mathrm{K}(0.121-$ $0.547 \mathrm{mg} / \mathrm{g})$, Ca (3.835-57.271 mg/g) and $\mathrm{Mg}(9.306-51.987 \mathrm{mg} / \mathrm{g})$. Meanwhile, brown algae recorded different ranges of $\mathrm{Na}(0.960-1.508 \mathrm{mg} / \mathrm{g}), \mathrm{K}(0.156-0.906$ $\mathrm{mg} / \mathrm{g})$, Ca $(9.824-93.922 \mathrm{mg} / \mathrm{g})$ and $\mathrm{Mg}(14.897-44.978 \mathrm{mg} / \mathrm{g})$. Red algae showed various contents of $\mathrm{Na}(0.763-1.767 \mathrm{mg} / \mathrm{g}), \mathrm{K}(0.072-0.773 \mathrm{mg} / \mathrm{g}), \mathrm{Ca}$ (14.706$352.266 \mathrm{mg} / \mathrm{g})$ and $\mathrm{Mg}(12.901-89.514 \mathrm{mg} / \mathrm{g})$. Concentration of $\mathrm{Na}$ followed as red algae $>$ brown algae $>$ green algae; $\mathrm{K}$ followed as brown algae $>$ red algae $>$ green algae; Ca followed as red algae > brown algae > green algae and $\mathrm{Mg}$ followed as red algae $>$ green algae $>$ brown algae (Table 1$)$.

Table 1: Essential minerals and essential trace elements in different species of algae collected from Alexandria, Egyptian Mediterranean Sea coast.

\begin{tabular}{|c|c|c|c|c|c|c|c|c|}
\hline Algae species & $\begin{array}{c}\mathrm{Na} \\
(\mathrm{mg} / \mathrm{g})\end{array}$ & $\begin{array}{c}\mathrm{K} \\
(\mathrm{mg} / \mathrm{g}) \\
\end{array}$ & $\begin{array}{c}\mathrm{Ca} \\
(\mathrm{mg} / \mathrm{g})\end{array}$ & $\begin{array}{c}\mathrm{Mg} \\
(\mathrm{mg} / \mathrm{g}) \\
\end{array}$ & $\begin{array}{c}\mathrm{Fe} \\
(\mathrm{Mg} / \mathrm{g})\end{array}$ & $\begin{array}{c}\mathrm{Cu} \\
(\mathrm{Mg} / \mathrm{g}) \\
\end{array}$ & $\begin{array}{c}\mathrm{Zn} \\
(\mathrm{Mg} / \mathrm{g})\end{array}$ & $\begin{array}{c}\mathrm{Mn} \\
(\mathrm{Mg} / \mathrm{g}) \\
\end{array}$ \\
\hline \multicolumn{9}{|l|}{ Green algae } \\
\hline Ulva linza, Abu Quir & 1.339 & 0.320 & 57.271 & 28.698 & 314.737 & 2.982 & 42.122 & 28.790 \\
\hline Ulva fasciata, Abu Quir & 1.012 & 0.547 & 29.399 & 38.638 & 501.834 & 4.279 & 22.738 & 31.589 \\
\hline Ulva fasciata, Sheraton & 1.340 & 0.533 & 17.141 & 51.987 & 283.847 & 1.222 & 18.206 & 35.802 \\
\hline Ulva fasciata, Stanlly & 1.164 & 0.415 & 3.835 & 9.306 & 126.871 & 1.871 & 19.461 & 29.990 \\
\hline Ulva fasciata, El-Shatby & 1.099 & 0.522 & 9.980 & 42.376 & 389.442 & 7.719 & 13.073 & 37.849 \\
\hline Ulva fasciata, E. Harbour & 0.998 & 0.540 & 4.963 & 27.094 & 102.526 & 4.210 & 58.321 & 19.936 \\
\hline Ulva fasciata, Agamy & 0.678 & 0.121 & 12.352 & 10.490 & 146.450 & 4.931 & 39.448 & 23.817 \\
\hline mean & 1.090 & 0.428 & 19.277 & 29.791 & 266.529 & 3.887 & 30.481 & 29.681 \\
\hline \multicolumn{9}{|l|}{ brown algae } \\
\hline Sargassum vulgare, Abu Quir & 0.960 & 0.769 & 93.922 & 0.960 & 2119.388 & 22.077 & 30.340 & 66.169 \\
\hline Colpomenia sinuosa, Abu Quir & 1.508 & 0.906 & 69.583 & 1.508 & 1360.863 & 10.045 & 29.638 & 53.770 \\
\hline Colpomenia sinuosa, Agamy & 1.042 & 0.156 & 9.824 & 1.042 & 805.761 & 0.615 & 42.959 & 48.535 \\
\hline mean & 1.170 & 0.610 & 57.770 & 1.170 & 1428.670 & 10.912 & 34.312 & 56.158 \\
\hline \multicolumn{9}{|l|}{ Red algae } \\
\hline Amphiroa rigida, Abu Quir & 1.376 & 0.136 & 352.266 & 1.376 & 851.196 & 16.724 & 28.687 & 102.222 \\
\hline Corallina officinalis, Abu Quir & 1.117 & 0.186 & 30.722 & 1.117 & 272.964 & 0.621 & 37.115 & 44.079 \\
\hline Pterocladia capillacea, Abu Quir & 0.763 & 0.773 & 37.020 & 0.763 & 1412.438 & 10.837 & 62.315 & 54.470 \\
\hline Pterocladia capillacea, Agamy & 0.819 & 0.072 & 14.706 & 0.819 & 269.325 & 1.223 & 22.872 & 19.606 \\
\hline Jania rubens, Abu Quir & 1.767 & 0.319 & 39.352 & 1.767 & 539.764 & 6.259 & 25.773 & 125.908 \\
\hline mean & 1.168 & 0.297 & 94.813 & 1.168 & 561.184 & 7.132 & 35.352 & 69.257 \\
\hline
\end{tabular}

On the other hand amongst essential trace elements ( $\mathrm{Fe}, \mathrm{Cu}, \mathrm{Zn}$ and $\mathrm{Mn}$ ) the iron contents were found to be the highest while, $\mathrm{Cu}$ contents were the lowest. Fe measured the highest mean value, $1428.670 \mu \mathrm{g} / \mathrm{g}$ in brown algae and $\mathrm{Cu}$ measured the lowest mean value, $3.887 \mu \mathrm{g} / \mathrm{g}$ in green algea. In green algae the highest value of $\mathrm{Fe}, 501.834 \mu \mathrm{g} / \mathrm{g}$ and the lowest value of $\mathrm{Cu}, 1.222 \mu \mathrm{g} / \mathrm{g}$. In brown algae Fe measured the highest value $2119.388 \mu \mathrm{g} / \mathrm{g}$ and $\mathrm{Cu}$ measured the lowest value $0.615 \mu \mathrm{g} / \mathrm{g}$. In red algae Fe recorded 1412.438 as the highest value and $\mathrm{Cu}$ measured the lowest value of $0.621 \mu \mathrm{g} / \mathrm{g}$. Most of seaweeds showed high level of $\mathrm{Zn}$ metal, where the mean values varied from $30.481 \mu \mathrm{g} / \mathrm{g}$ in green algae to 34.312 in brown algae and 35.352 in red algae. Where, $\mathrm{Zn}$ content followed as red algae $>$ brown algae $>$ green algae. The results indicated that the highest 
values of $\mathrm{Zn}(62.315$ and $58.321 \mu \mathrm{g} / \mathrm{g})$ were recorded in red and green algae, respectively while, the lowest one was found in green algae $(13.073 \mu \mathrm{g} / \mathrm{g})$. High levels of Mn metal were found in studied algea. The mean values varied from $29.681 \mu \mathrm{g} / \mathrm{g}$ in green algae to 56.158 in brown algae and 69.257 in red algae. Where, Mn content followed as red algae $>$ brown algae > green algae. The highest values of Mn (125.908 and $102.222 \mu \mathrm{g} / \mathrm{g})$ were recorded in red algae while, the lowest ones $(19.606$ and $19.936 \mu \mathrm{g} / \mathrm{g})$ were found in red and green algae, respectively (Table 1).

Table 2 represented concentrations of essential minerals $(\mathrm{Na}, \mathrm{K}, \mathrm{Ca}$ and $\mathrm{Mg}$ ) and essential trace elements $(\mathrm{Fe}, \mathrm{Cu}, \mathrm{Zn}$ and $\mathrm{Mn}$ ) in studied stations water. Mean values of essential minerals concentration recorded, $\mathrm{Na} 11.353 \mathrm{~g} / \mathrm{l}, \mathrm{K} 0.519 \mathrm{~g} / \mathrm{l}, \mathrm{Ca} 0.513 \mathrm{~g} / \mathrm{l}$ and $\mathrm{Mg} 1.895 \mathrm{~g} / \mathrm{l}$. It was observed that Agamy station has the smallest values of $\mathrm{Na}(10.560$ $\mathrm{g} / \mathrm{l}), \mathrm{K}(0.463 \mathrm{~g} / \mathrm{l}), \mathrm{Ca}(0.473 \mathrm{~g} / \mathrm{l})$ and $\mathrm{Mg}(1.573 \mathrm{~g} / \mathrm{l})$. The mean values of essential trace elements concentrations in stations water recorded, Fe (342.587 $\mathrm{Mg} / \mathrm{l}), \mathrm{Cu}(9.760 \mathrm{Mg} / \mathrm{l})$, $\mathrm{Zn}(5.767 \mathrm{mg} / \mathrm{l})$ and $\mathrm{Mn}(1.979 \mathrm{Mg} / \mathrm{l})$. They followed as $\mathrm{Fe}>\mathrm{Cu}>\mathrm{Zn}>\mathrm{Mn}$. The highest values of $\mathrm{Fe}(565.505 \mathrm{Mg} / \mathrm{l}), \mathrm{Zn}(20.756 \mathrm{Mg} / \mathrm{l})$ and $\mathrm{Mn}(4.803 \mathrm{Mg} / \mathrm{l})$ were recorded at Abu Quir station while, $\mathrm{Cu}$ measured the highest values 28.260, 10.242 and $8.425 \mathrm{Mg} / 1$ at Agamy, El-Shatby and Eastern Harbour, respectively.

Table 2: Essential minerals and essential trace elements in seawater.

\begin{tabular}{|l|c|c|c|c|c|c|c|c|}
\hline Stations & $\mathrm{Na}(\mathrm{g} / \mathrm{l})$ & $\mathrm{K}(\mathrm{g} / \mathrm{l})$ & $\mathrm{Ca}(\mathrm{g} / \mathrm{l})$ & $\mathrm{Mg}(\mathrm{g} / \mathrm{l})$ & $\mathrm{Fe}(\mathrm{Mg} / \mathrm{l})$ & $\mathrm{Cu}(\mathrm{Mg} / \mathrm{l})$ & $\mathrm{Zn}(\mathrm{Mg} / \mathrm{l})$ & $\mathrm{Mn}(\mathrm{Mg} / \mathrm{l})$ \\
\hline Abu Quir & 11.490 & 0.536 & 0.505 & 1.955 & 565.505 & 3.836 & 20.756 & 4.803 \\
\hline Sheraton & 11.820 & 0.526 & 0.497 & 1.935 & 335.341 & 3.907 & 6.250 & 1.184 \\
\hline Stanlly & 11.330 & 0.534 & 0.537 & 1.997 & 164.540 & 3.893 & 1.929 & 0.926 \\
\hline El-Shatby & 11.600 & 0.537 & 0.537 & 1.997 & 451.257 & 10.242 & 2.767 & 2.068 \\
\hline E. Harbour & 11.320 & 0.521 & 0.529 & 1.916 & 98.482 & 8.425 & 0.899 & 0.605 \\
\hline Agamy & 10.560 & 0.463 & 0.473 & 1.573 & 440.400 & 28.260 & 2.003 & 2.291 \\
\hline mean & $\mathbf{1 1 . 3 5 3}$ & $\mathbf{0 . 5 1 9}$ & $\mathbf{0 . 5 1 3}$ & $\mathbf{1 . 8 9 5}$ & $\mathbf{3 4 2 . 5 8 7}$ & $\mathbf{9 . 7 6 0}$ & $\mathbf{5 . 7 6 7}$ & $\mathbf{1 . 9 7 9}$ \\
\hline
\end{tabular}

Physical and chemical parameters of studied stations water were given in Table 3. Water temperature ranged between $22.0{ }^{\circ} \mathrm{C}$ at Sheraton station and $26.5{ }^{\circ} \mathrm{C}$ at Eastern Harbour. Salinity values varied with a maximum value $(37.45 \%$ ) at Stanly and a lowest value (34.33\%) at Agamy. The highest $\mathrm{pH}$ value (8.48) was recorded at El-Shatby and the lowest value (8.03) was observed at Eastern Harbour. Total alkalinity (TA) values ranged between $2.60 \mathrm{meq} / \mathrm{l}$ at Abu Quir and $3.00 \mathrm{meq} / \mathrm{l}$ at Agamy.

Table 3: Physical and chemical parameters of seawater.

\begin{tabular}{|c|c|c|c|c|c|c|c|c|}
\hline Stations & $\begin{array}{c}\text { Temperature, } \\
\mathrm{T}\left({ }^{\circ} \mathrm{C}\right)\end{array}$ & $\begin{array}{l}\text { Salinity, } \\
(\% \text { ) }\end{array}$ & $\mathrm{pH}$ & $\begin{array}{c}\text { Total Alkalinity, } \\
\text { TA (meq/l) }\end{array}$ & $\begin{array}{c}\mathrm{OOM}, \\
\left(\mathrm{mg} \mathrm{O}_{2} / \mathrm{l}\right)\end{array}$ & $\begin{array}{c}\mathrm{DO}, \\
\left(\mathrm{ml} \mathrm{O}_{2} / \mathrm{l}\right)\end{array}$ & $\begin{array}{c}\text { ammonium, } \\
(\mathrm{MM} / \mathrm{l})\end{array}$ & $\begin{array}{l}\text { Chlorophyl a, } \\
\text { Chl-a (Mg/l) }\end{array}$ \\
\hline Abu Quir & 25.0 & 35.84 & 8.15 & 2.60 & 1.216 & 7.874 & 3.45 & 0.552 \\
\hline Sheraton & 22.0 & 37.17 & 8.09 & 2.80 & 1.824 & 7.022 & 26.40 & 0.612 \\
\hline Stanly & 26.0 & 37.45 & 8.09 & 2.75 & 3.344 & 6.597 & 12.65 & 1.895 \\
\hline El-Shatby & 22.5 & 35.62 & 8.48 & 2.95 & 6.688 & 7.661 & 3.05 & 6.999 \\
\hline E. Harbour & 26.5 & 36.82 & 8.03 & 2.70 & 2.432 & 3.405 & 4.50 & 1.392 \\
\hline Agamy & 25.0 & 34.33 & 8.14 & 3.00 & 0.912 & 6.703 & 11.85 & 0.301 \\
\hline
\end{tabular}

The levels of OOM ranged between $0.912 \mathrm{mg} \mathrm{O} / 2$ at Agamy and $6.688 \mathrm{mg} \mathrm{O}_{2} / 1$ at El-Shatby. The minimum value of DO $\left(3.405 \mathrm{ml} \mathrm{O}_{2} / \mathrm{l}\right)$ was recorded at Eastern Harbour while the maximum one $\left(7.874 \mathrm{ml} \mathrm{O}_{2} / \mathrm{l}\right)$ was recorded at Abu Quir. The maximum value of ammonium $(26.40 \mathrm{MM} / \mathrm{l})$ appeared at Sheraton station and the minimum one $(3.05 \mathrm{MM} / \mathrm{l})$ appeared at El-Shatby. The levels of Chl-a in the studied water varied from $0.301 \mathrm{Mg} / \mathrm{l}$ at Agamy to $6.999 \mathrm{Mg} / \mathrm{l}$ at El-Shatby. 
Proximate content (carbohydrates and proteins) of algae

Proximate content in the three types of algae recorded as follow, for carbohydrates red algae $>$ green algae $>$ brown algae (136.127, 114.167 and 67.320 $\mathrm{mg} / \mathrm{g}$ ). Meanwhile, proteins concentration followed as red algae > brown algae > green algae (1.164, 0.946 and $0.882 \mathrm{~g} \%$ ) (Table 4).

Table 4: Proximate content (carbohydrates, $\mathrm{mg} / \mathrm{g}$ and proteins, $\mathrm{g} \%$ ) of different species of algae.

\begin{tabular}{|l|c|c|}
\hline Algae species & Total Carbohydrates, $(\mathrm{mg} / \mathrm{g})$ & Total proteins, $(\mathrm{g} \%)$ \\
\hline Green algae & & 1.431 \\
\hline Ulva linza, Abu Quir & 82.010 & 1.010 \\
\hline Ulva fasciata, Abu Quir & 134.790 & 1.200 \\
\hline Ulva fasciata, Sheraton & 94.420 & 1.154 \\
\hline Ulva fasciata, Stanlly & 124.420 & 0.185 \\
\hline Ulva fasciata, El-Shatby & 146.730 & 0.461 \\
\hline Ulva fasciata, E. Harbour & 91.430 & 0.739 \\
\hline Ulva fasciata, Agamy & 125.370 & $\mathbf{0 . 8 8 2}$ \\
\hline mean & $\mathbf{1 1 4 . 1 6 7}$ & 0.092 \\
\hline brown algae & & 1.800 \\
\hline Sargassum vulgare, Abu Quir & 57.500 & $\mathbf{0 . 9 4 6}$ \\
\hline Colpomenia sinuosa, Abu Quir & 77.140 & 1.476 \\
\hline mean & $\mathbf{6 7 . 3 2 0}$ & 2.030 \\
\hline Red algae & & 0.738 \\
\hline Amphiroa rigida, Abu Quir & 34.720 & 0.415 \\
\hline Corallina officinalis, Abu Quir & 124.740 & $\mathbf{1 . 1 6 4}$ \\
\hline Pterocladia capillacea, Abu Quir & 264.710 & $\mathbf{1 3 6 . 1 2 7}$ \\
\hline Jania rubens, Abu Quir & 120.340 & \\
\hline mean & & \\
\hline
\end{tabular}

\section{Ion quotient}

To identify minerals in water, magnesium and calcium contents (hardness) and the ratio of them are usually determined. The ion quotient can be studied not only for water but also for plants, animals and humans. It is calculated from the following equation and the concentrations are expresed in moles (Csikkel-Szolnoki et al., 2000; Kiss et al., 2004).

Ion quotient $=\left[\mathrm{Ca}^{2+}+\mathrm{Na}^{2+}\right] /\left[\mathrm{Mg}^{2+}+\mathrm{K}^{2+}\right]$

From Table 5 the ion quotients were in the range of 0.208- 2.019 for green algae and 0.722-2.087 for brown algae. Meanwhile, for red algae they were in the range of $0.458-2.433$.

Table 5: Ion quotients in the different algae species.

\begin{tabular}{|l|l|l|}
\hline Stations & Algae species & IQ \\
\hline & Green Algae & \\
\hline Abu Quir & Ulva Linza & 2.019 \\
\hline Abu Quir & Ulva Fasciata & 0.776 \\
\hline Sheraton & Ulva Fasciata & 0.352 \\
\hline Stanly & Ulva Fasciata & 0.514 \\
\hline El-Shatby & Ulva fasciata & 0.256 \\
\hline E. Harbour & Ulva fasciata & 0.208 \\
\hline Agamy & Ulva fasciata & 1.228 \\
\hline & Brown Algae & \\
\hline Abu quir & Sargassum Vulgare & 2.074 \\
\hline Abu quir & Colpomenia Sinuosa & 2.087 \\
\hline Agamy & Colpomenia Sinuosa & 0.722 \\
\hline & Red Algae & \\
\hline Abu Quir & Amphiroa Rigida & 0.513 \\
\hline Abu Quir & Corallina Officinalis & 2.433 \\
\hline Abu Quir & Peterocladia Capillacea & 1.627 \\
\hline Abu Quir & Jania Rubens & 0.458 \\
\hline Agamy & Peterocladia Capillaceous & 1.039 \\
\hline
\end{tabular}




\section{DISCUSSION}

Mineral nutrients are inorganic elements wanted in littel quantities ranging from less than 1 to $2500 \mathrm{mg}$ per day, basing on the type of minerals. They are essential for maintaining certain physico-chemical processes necessary for life (Eruvbetine, 2003).

\section{Essential minerals}

It is difficult to compare calcium content in algae collected from different countries due to dependence of calcium concentration on physical parameters of water where, calcium concentrations are high in alkaline medium and low in acidic medium (Brody, 1994). Red algae recorded higher calcium content than that in brown and green algae (Table 1). Calcium is important because of its role in bone, teeth, muscles and heart functions. Meanwhile, values of sodium and potassium differed in algae collected from various places and in different types of algae (Table 1). Increasing the concentration of potassium in the blood leads to decreased kidney function, unusual destroy of protein, inflammation of infection and damage of the intestine. $\mathrm{Na}$ has an essential participation in the metabolites transportation. The $\mathrm{K} / \mathrm{Na}$ ratio in meals is a very important factor in forbidding of hypertension and arteriosclerosis (Saupiet al., 2009).

Concentration of $\mathrm{Mg}$ presented in high value in red algae followed by brown algae (Table 1). In humans, $\mathrm{Mg}$ is wanted in plasma and extracellular fluid, as it assists maintaining an osmotic balance. It is demanded in various catalyst enzyme interactions, particularly those involving nucleotides where the active species are magnesium salts. Decrease of $\mathrm{Mg}$ is correlated with uncommon irritability of muscles and convulsions while, increase of $\mathrm{Mg}$ is associated with depression in the central nervous system (Bhowmiketal., 2012). Magnesium are good for building of red blood cells, fixing of worn out cells and preserving body mechanisms (WHO, 1996). Lack of magnesium and calcium in food may cause weak, bad bone expansion and stunted growth (Effiong and Udo, 2010). From the data of ion quotient, the molar concentration revealed that feeding on all species of algae can reduce hypertension, preeclampsia and heart disease (Table 5).

\section{Essential trace elements}

The highest concentration of iron was found in brown algae and then in red algae, the lowest one was found in green algae (Table 1). Iron plays an important role in human health. Iron is a main component of hemoglobin formation, normal functioning of the central nervous system and oxidation of proteins, carbohydrates and fats (Odhav et al., 2007). On the other hand, the value of $\mathrm{Cu}$ in the investigated samples varied between the highest value in brown algae followed by red algae meanwhile, the lowest value recorded in green algae (Table 1). The differences in content of metals in the studied algae depend on the physico-chemical nature of the sediments and the metal absorption capacity of each algae, which affected by different factors such as environmental and human interference. Copper is an important essential element to living organisms. It acts as a component of many biooxidation enzymes. It exists in plasma protein of blood as erythrocuprin. Copper is the essential micronutrient needed for the hematological and neural system (Tan et al., 2006).

The content of zinc existed in relatively similar amounts in the studied algal species. Maximum concentration recorded in red algae and the lowest one found in green algae (Table 1). Zinc is a very important mineral for natural growth in humans. Referring to FAO's food budget reports, nearly $20 \%$ of the people around the world are considered to be at danger of zinc insufficiency (Allen et al., 2006). It could be 
because of food deficiency, poor absorption, too much secretion, or inherited defects in zinc metabolism. $\mathrm{Zn}$ is considered as a basic metal for the work of different enzymes. Lack of $\mathrm{Zn}$ in children, may cause loss of appetite, delayed growth and stagnation of sexual growth (Saracoglu et al., 2009). Manganese content in the studied macroalgae followed as red algae $>$ brown algae $>$ green algae (Table 1). Manganese activates the formation of amino acids, activates certain enzymes and activates co enzyme. It acts as a cofactor of the enzyme which is a mitochondrial superoxide dismutase. Manganese is portion of the enzymes participating in the formation of urea. Manganese is concentrated in the mitochondria, where it participates in oxidative phosphorylation partial regulation. Manganese absorption is prevented by excessive amounts of phosphate and calcium in food (Tan et al., 2006).

\section{Proximate content}

Carbohydrates are the primary energy reserves in adults. Polysaccharides extracted from algae showed good immune effects in vitro and also in vivo (Pasco and Pugh, 2010; Suárez et al., 2010; Watanabe and Seto, 1989). From this study, approximately the concentration of carbohydrates in green and red algae were the same. Proteins are the basic units for the production of vital tissues and enzymes in all animals. Therefore, the dietary protein must be sufficient for tissue production and metabolic processes. The rapidly growing cells are characterized by high protein and low carbohydrate content $(\mathrm{CHO})$. When cells reach a fixed stage, more carbon is incorporated into CHO and/or fat (Zhu et al., 1997; El-Said and El-Sikaily, 2013). Proteins percentage varied to a large degree in the studied algae species. Amongst the investigated algae, red and green species possessed high percentages of proteins (dry weight \%) while, lower percentages were found in brown algae species. Carbohydrates and Proteins that run away from digestion in the small intestine are very important for humans. They indirectly stimulate the immune response by raising microbial reactions (Cian et al., 2015). The dietary modification of colonic flora plants and the effect of bacterial fermentation products on human health are under investigation (Angell et al., 2016; Dawczynskiet al., 2007; Holdt and Kraan, 2011; Pereira, 2011; Taboada et al., 2013). Duffy et al., 2015 found that, the mean concentration of proteins in brown and green algae were the same. This finding was not in agreement with the results of this study.

\section{CONCLUSION}

Algae consumption is increasing for functional benefits beyond traditional nutrition and health considerations. The most important nutrients for disease resistance are $\mathrm{Na}, \mathrm{K}, \mathrm{Ca}, \mathrm{Mg}, \mathrm{Fe}, \mathrm{Cu}, \mathrm{Zn}$ and $\mathrm{Mn}$. Therefore, this research sought to study the basic minerals and trace elements in green, brown and red algae as well as to study the chemical composition of these algae (carbohydrates and proteins). According to the presented results, the investigated species of algae can be considered as a good source of polysaccharides. Among marine algae, red and green algae often contain high levels of proteins while, low values are recorded in brown algae. The mineral content differences in studied species based on the physicochemical properties of the sediments and the ability of metal to be absorbed by algae from the ecosystem, which are modified by different factors such as environmental and human interference. Besides the fact that algae act as a source of nutrients, red algae recorded a high percentage of calcium, including in brown and green algae. Owing to the computed ion quotient data, all presented algal species can help in 
decreasing symptoms of some diseases including, hypertension, preeclampsia and cardiac disease.

\section{ACKNOWLEDGMENT}

The authors are thankful to Dr. Mona M. Ismail (Taxonomy and biodiversity of aquatic biota Lab., National Institute of Oceanography and Fisheries, Alexandria branch) for her efforts in systematic identification of the collected seaweed spp.

\section{REFERENCES}

Aleem, A.A. (1993). Marine algae of Alexandria, Egypt. Alexandria: Privately published.

Allen, L.; Benoist, B.; Dary, O. and Hurrell, R. (2006). Guidelines on food fortification with micronutrients, World Health Organization and Food and Agriculture Organization of the United Nations.WHO Press, Geneva, Switzerland.

American Public Health Association, APHA-AWWA-WPCF (1999). Standard Methods for the Examination of Water and Waste Water, $20^{\text {th }}$ edition. American Public Health Association, Washington, DC, USA.

Angell, A.R.; Mata, L.; de Nys, R. and Paul, N.A. (2016). The protein content of seaweeds: a universal nitrogen-to-protein conversion factor of five. J. Appl. Phycol., 28: 511-524.

Bagchi, D. (2006). Nutraceuticals and functional foods regulations in the United States and around the world. Toxicology, 221(1): 1-3.

Becker, W. (2004). Microalgae in human and animal nutrition. In: "Handbook of microalgal culture." Richmond, A. (Ed.). Blackwell, Oxford, pp. 312- 351.

Bhowmik, S.; Datta, B.K. and Saha, A.K. (2012). Determination of mineral content and heavy metal content of some traditionally important aquatic plants of tripura, India using atomic absorption spectroscopy. J. Agricultural Technology, 8(4): 1467-1476.

Brody, T. (1994). Nutritional Biochemistry. San Diego Academic Press, San Diego.

Caliceti, M.; Argees, E.; Sfriso, A.; Pavoni, B. (2002). Heavy metal concentration in the seaweeds of the Venic lagoon. Chemosphere, 47: 443-454.

Cian, R.E.; Drago, S.R.; de Medina, F.S.; Martinez-Augustin, O. (2015). Proteins and carbohydrates from red seaweeds: evidence for beneficial effects on gut function and microbiota. Marine Drugs, 13: 5358-5383.

Cost 48 (1987). Aquatic primary biomass (marine macro algae) biomass conversion, removal and use of nutrients. Proceeding of the $1^{\text {st }}$ workshop of subgroup 3, Cremal' Houmeau, CNRS-IFREMER, L' Houmeau, France. Commision of European Communities, Brussels, pp. 140.

Cost 48 (1989). Aquatic primary biomass (marine macro algae) outdoor seaweeds seaweed cultivation. Proceeding $2^{\text {nd }}$ workshop of subgroup 1, Port erin, isle of man, british isles. Commision of European Communities, Brussels, pp. 120.

Csikkel-Szolnoki, A.; Báthori, M. and Blunden, G. (2000). Determination of elements in algae by different atomic spectroscopic methods. Microchemical Journal, 67: 39-42.

Dawczynski, C.; Schäfer, U.; Leiterer, M. and Jahreis, G. (2007). Nutritional and toxicological importance of macro, trace, and ultra-trace elements in algae food products. J. Agric. Food Chem., 55: 10470-10475.

DuBois, M.; Gilles, K.A.; Hamilton, J.K.; Rebers, P.A. and Smith, F. (1956). Colorimetric Method for Determination of Sugars and related Substances. Anal. Chem., 28(3): 350356.

Duffy, L.C.; Raiten, D.J.; Hubbard, V.S. and Starke-Reed, P. (2015). Progress and challenges in developing metabolic footprints from diet in human gut microbial cometabolism. J. Nutr., 145: 1123S-1130S.

Effiong, G.S. and Udo, I.F. (2010). Nutritive value of indigenous wild fruits in Southeastern Nigeria. Electronic J. Environ. Agric. Food Chem., 9: 1168-1176. 
El-Said, G.F. and El-Sikaily, A. (2013). Chemical composition of some seaweed from Mediterranean Sea coast, Egypt. Environ. Monit. Assess., 185: 6089-6099.

Eruvbetine, D. (2003). Canine Nutrition and Health. A paper presented at the seminar organized by Kensington Pharmaceuticals Nig. Ltd., Lagos on August 21, 2003.

FAO (1976). Manual of Methods in Aquatic Environmental Research Part 1: Permanganate Value (Oxidisability) of Organic Matter in Natural Waters. FAO Fisheries Technical paper, 137: 169-174.

Hafting, J.T.; Critchley, A.T.; Cornish, M.L.; Hubley, S.A.; Archibald, A.F. (2012). On-land cultivation of functional seaweed products for human usage. J. Appl. Phycol., 24: 385392.

Hays, V.W. and Swenson, M.J. (1985). Minerals and Bones. In: "Dukes Physiology of Domestic Animals."10 $0^{\text {th }}$ ed. Cornell University Press, London, UK, pp. 449-466.

Holdt, S.L. and Kraan, S. (2011). Bioactive compounds in seaweed: functional food applications and legislation. J. Appl. Phycol., 23: 543-597.

Intergovernmental Oceanographic Commission (IOC) (1983). "Nutrient Analysis in Tropical Marine waters". Manuals and Guides, UNESCO, 28: 1-24.

Jensen, A. (1993). Present and future needs for alga and algal products. Hydrobiology, 260/261: 15-21.

Kiss, S.A.; Forster, T. and Dongo, A. (2004). Absorption and effect of the magnesium content of a mineral water in the human body. Journal of the American College of Nutrition, 23(6): 758S-762S.

Kreeger, D.A.; Goulden, C.; Kilham, S.; Lynn, S.; Datta, S. and Interlandi, S. (1997). Seasonal changes in the biochemistry of lake seston. Freshwat. Biol., 38: 539-554.

Lowry, O.H.; Rosebrough, N.J.; Farr, A.L. and Randall, R.J. (1951). Protein measurements with folinphenol reagent. J. Biol. Chem., 193: 265-275.

MAA, Ministério da Agricultura e Abastecimento (1998). Compêndio brasileiro de alimentação animal: matéria-prima. Brasília: Sindirações/ANFAR; CBNA; SDR/MA.

Odhav, B.; Beekrum, S.; Akula, U. and Baijnat, H. (2007). Preliminary assessment of nutritional value of traditional vegetables in KwaZulu-Natal, South Africa. J. Food Comp. Anal., 20: 430-435.

Ozcan, M. (2003). Mineral Contents of some Plants used as condiments in Turkey. Food Chemistry, 84: 437-440.

Pasco, D. and Pugh, N. (2010). Potent immunostimulatory extracts from microalgae. US Patent, 7846452 B2.

Pereira, L. (2011). A review of the nutrient composition of selected edible seaweeds. In: "Seaweeds: ecology, nutrient composition and medicinal uses." Ponin, V.H. (Ed.). Nova Science Publishers Inc., Coimbra, pp. 15-47.

Riedel, R. (1970). Fauna and flora der Adria. Parey, Hamburg.

Riley, J.P. and Taylor, D. (1968). Chelating Resins for the Concentration of Trace Elements from Sea Water and Their Analytical Use in Conjunction with Atomic Absorption Spectrophotometry. Analytica Chimica Acta, 40: 479-485.

Rupérez, P. (2002). Mineral content of edible marine seaweed. Food chem., 79: 23-26.

Saracoglu, S.; Tuzen, M. and Soylak, M. (2009). Evaluation of trace element contents of dried apricot samples from Turkey. J. Hazard. Mater., 167: 647-652.

Saupi, N.; Zakira, M.H. and Bujang, J.S. (2009). Analytic chemical composition and mineral content of yellow velvet leaf (Limnocharis flava L. Buchenau) edible parts. J. Appl. Scie., 9: 2969 -2974.

Schüep, W. and Schierle, J. (1995). Determination of stabilized, added astaxanthin in fish feeds and pre-mixes. In: "Carotenoids isolation and analysis". Britton, G.; LiaaenJensen, S.\&Pfander, H. (Eds.). Birkhäuser Verlag, Basel, Switzerland, pp. 273-276.

Strickland, J.D.H. and Parsons,T.R. (1972). A Practical Handbook of Sea Water Analysis, seconded. Fish. Res. Bd., Canada Bull. 167, 1-310.

Suárez, E.R.; Kralovec, J.A. and Grindley, T.B. (2010). Isolation of phosphorylated polysaccharides from algae: the immunostimulatory principle of Chlorella pyrenoidosa. Carbohydr. Res., 345: 1190-1204. 
Taboada, M.C.; Millán, R. and Miguez, M.I. (2013). Nutritional value of the marine algae wakame (Undaria pinnatifida) and nori (Porphyra purpurea) as food supplements. J. Appl. Phycol., 25: 1271-1276.

Tan, J.C.; Burns, D.L. and Jones, H.R. (2006). Severe ataxia, myelopathy and peripheralneuropathy due to acquired copper deficiency in a patient with history of gastrectomy. J. Parenter Enteral Nutr., 30: 446-450.

Watanabe, S. and Seto, A. (1989). Ingredient effective for activating immunity obtained from Chlorella minutissima. US Patent, 4831020 A.

WHO, (1996). Trace Elements in Human Nutrition and Health. World Health organization, Geneva.

Zhu, C.J.; Lee, Y.K. and Chao, T.M. (1997). Effects of temperature and growth phase on lipid and biochemical composition of Isochrysis galbana TK1. J. Appl. Phycol., 9: 451-457.

\footnotetext{
ARABIC SUMMARY

القيمه الغذائيه و الصحيه للطحالب التي تم جمعها من الساحل المصري، الاسكندريه

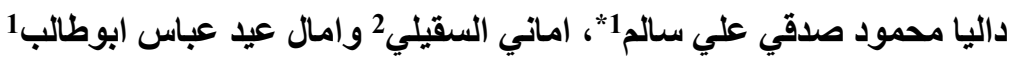

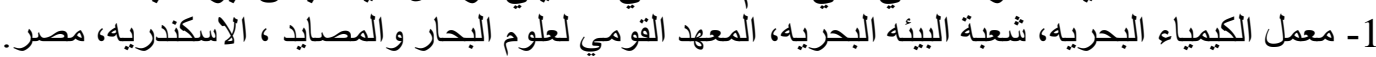

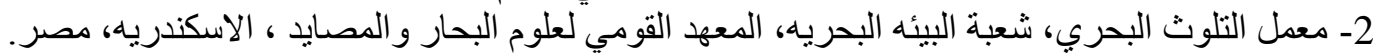

الطحالب البحرية لها اهيه كبيره وذلك بسبب القيمه الغذائيه و الصحيه العاليه التي يمكن ان تمد الانسان بها. وبناء

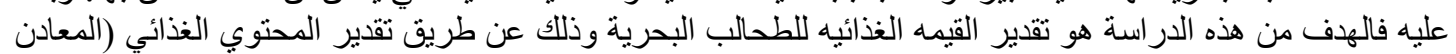

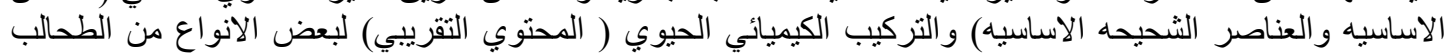

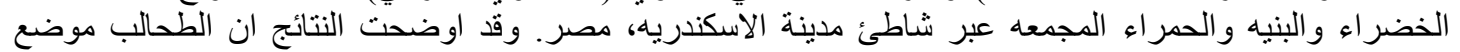

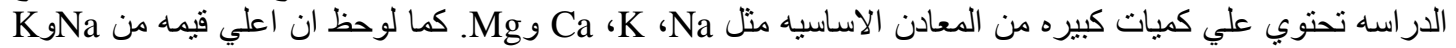

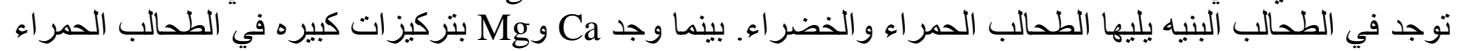

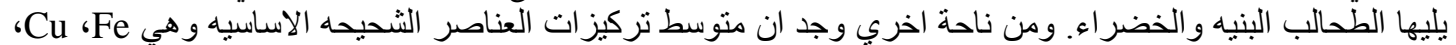

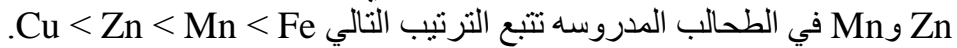

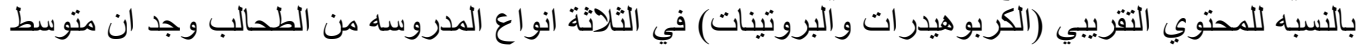

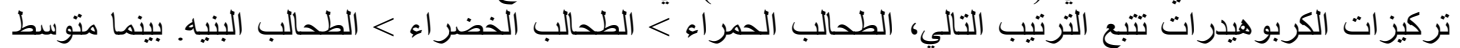

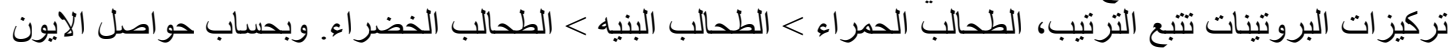

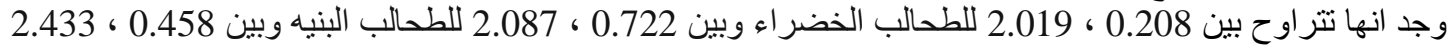

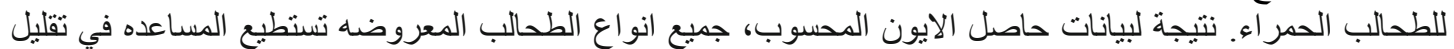

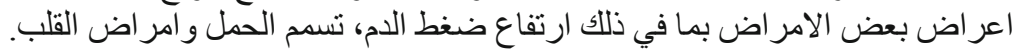

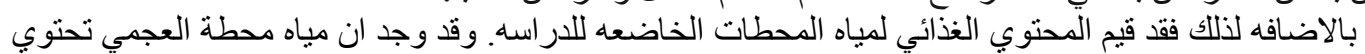

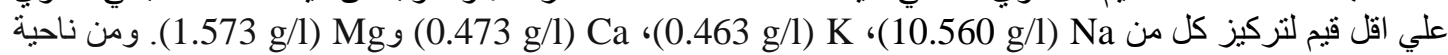
اخري فقد وجد ان العناصر الثحيحه الاساسيه في مياه المحطات المدروسه تنتبع الترتيب التالي

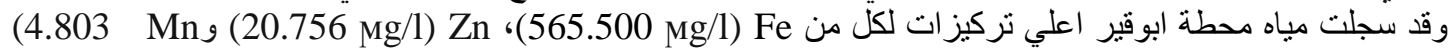
(28.260 Mg/l) Cu وجدت في مياه محطة العجمي.
} 